\title{
From the Middle Ages to modern times: the Karelian female name system
}

This paper ${ }^{1}$ offers an analysis of the system of female names used among the Karelian population. In addition to the analysis of the forms of Christian names used in the past and present in the territory populated by ethnic Karelians in the Republic of Karelia, as well as in Finland and the Tver and Leningrad Regions, an attempt is made to reconstruct the pre-Christian female name system of Medieval Korela. An important observation is that, as opposed to pre-Christian male names, which can be uncovered not only in documents but also in Karelian surnames and toponymy, there are no documented traces of female pre-Christian names from the Karelian population. At present, the main source of knowledge about Finnic pagan female names is, admittedly, oral folk poetry. The author, however, believes that there is another important source of information in addition to folklore, i.e. cow names, which can potentially offer quite a bit of data about the pre-Christian female name system of the Medieval Karelians. The pre-Christian system of female names began to gradually vanish from the Karelian land as Orthodoxy took over. After the baptizing event in 1227, the introduction of the Russian Orthodox onomasticon into the Karelian milieu led to the emergence of multiple vernacular variants. To account for these, the author analyzes the main patterns in the phonetic adaptation of Russian-language forms of female names in the Karelian language.

1. Research question and aims

2. Pre-Christian Karelian female names

3. Karelian Christian female names and their variants 
From the Middle Ages to modern times: the Karelian female name system

\section{Research question and aims}

The system of personal female names now in use among the Karelian population has taken shape as a result of a long process. At the same time, there are thus far no scientific papers specifically dealing with this matter. Fragmented notes, mostly lists of female names that were once the most common or still are in use in Karelian communities, can be found, for instance, in papers by Samuli Paulaharju (1924), Viljo Nissilä (1976), Pertti Virtaranta (1972, 1992), A. Gromova (1979) and Denis Kuzmin (2016).

One must acknowledge that the bulk of the formerly used female names and their variants still remains unidentified. Similarly, no targeted efforts have been made, in either Russia or Finland, to collect Karelian-language forms of Christian female names, with the exception of the works of Virtaranta, Paulaharju and Gromova (concerning the Padany sub-dialect). These too, however, mainly recorded only the most widely used forms of the names in question. The staff at the Karelian Research Center also began the collection of Karelian-language anthroponymy only recently. Before that, not much attention had been given to this issue during expeditions for a number of reasons. One of the reasons is, for example, that female names are only sporadically present in the Karelian toponymy. The largest group of anthroponymically derived denominations there comes from male Christian names. The reason for this is that the master of the house was almost always a man, and it was he who owned the homestead as well as engaged in various trades and crafts. The total number of records of female names in the toponymy of the northern parts of Karelia, for instance, was $10 \%$ of the total number of place names incorporating Christian names in the region. We mostly find these in the names of small geographic sites as well as agricultural features in the immediate vicinity of settlements (Kuzmin 2014: 56-57).

Oddly enough, it was owing to World War II and the related casualties that female names got a chance to step up. Some $40 \%$ of the male population of Karelian-speaking areas never returned from the war. After the war, their widows headed the families, and thus the number of homestead names with women's names fixed in them grew sharply. The names of land lots attached to the homestead also became more often based on women's names.

It is worth mentioning here that the scarcity of studies on either female names in general or the retrospective of their variants in Russia and the former USSR is due both to the governing theoretical approach to the analysis of female names and the lack of reliable field data for many 
territories. The complete corpus of variants of canonical female names for Russia is still non-existent, although researchers have produced some papers on some areas and general issues. One can mention, for instance, N.A. Petrovskiy's Dictionary of Russian Personal Names, as well as studies by A.V. Superanskaya, B.A. Uspenskiy, F.V. Stepanova, N.N. Parfyonova and some others. The number of vernacular variants presented in these has, however, been rather limited.

Since documentary sources are missing from the research toolkit, no studies have thus far considered the functioning of the Christian female name system in the first half of the 17 th century and earlier. Such studies could clarify the usage of certain forms of names among non-Russian peoples, for instance in Karelia. It is now not always clear how to explain the functioning of one Karelian-language variant or another, since we do not know which Russian-language form it was based on. Meanwhile, we know that many Karelian-language variants were derived not from the canonical name as such, but from its vernacular form that used to be common among the neighboring Russian population (Kuzmin 2016: 63). The name Ägräššie, to take one example, would have been difficult to analyze had we not known that the calendar name behind it was Agrafena $(<A g$ rippina). Knowing this, we can hypothesize that the Karelian-language variant is based on the vernacular form Agrasiya / Agras'ya / Agrashiya / Agrash'ya (cf. Kar. Nastassie - Anastasiya) or, possibly, Agrafiya. These forms, however, have not yet been recorded from the neighboring Russianspeaking areas. What makes this case even more complicated is that the Karelian-language form is a word with front vocalism, which is rather infrequent in anthroponymy.

The main reason for the lack of such studies is that female names only began to appear regularly in documentary sources during the third census, carried out early in the 1760 s. Prior to that, the various census, land survey and cadastral documents mainly recorded only the male population. Women's names could appear in documents, for instance, in connection with widowhood, when women were legally entitled to head the family. One of the probable origins of this phenomenon is the domostroy (household rules) tradition, which placed constraints on the involvement of women in public life (Zinin 1972: 89).

Thus, 1678 Survey Books (KP 1978) of seven Lop' pogosts mentioned only six women for this huge territory stretching from the former Vokhtozerskaya Volost in the south of Karelia to the border with present-day 
Murmansk Region in the north: viz. widow Irinitsa wife of Vasiliy (Panozero) (62 ob), widow Aksen'itsa wife of Mikhail (Kompakovo) (47 ob), widow Stefanidka daughter of Timofey (Rugozero) (45 ob), widow Fevron'itsa daughter of Alexey (Pelkula) (410b), widow Akilinka daughter of Andrey (Mudalaksha) (23 ob) and widow Irinitsa daughter of Fyodor (Myaranduksa) $(99 \mathrm{ob})$. A somewhat larger number of widowed women were mentioned in the Lop' pogosts' census books from 1707 ( $\mathrm{PK}$ 1707), following three lean years in a row in the mid-169os and possibly in connection with the beginning of the Great Northern War. A similar situation also occurred in the 16th-17th centuries in Korelskiy Uyezd in the Ladoga region. We have thus far identified 26 female names in the available census records, viz. Dompni (1618), Ortijsa (1618), Okulintke (1631) (IK 1987: 294, 303, 521); Malana (1637), Ostenia (1637) (IK 1991: 101, 192); Fenka (1629), Manka (1582), Orinka (1582), Ulitka (1582) (IK 1993: 155, 264, 275, 367), etc.

At the same time, research can examine a unique document - the 1650/51 Census of Karelian migrants in Bezhetskiy Verkh published by the Finnish researcher Veijo Saloheimo (1992). It contains information about 1,200 families of Karelians who moved to the north-eastern part of the Tver Region after the 1617 Peace of Stolbovo. The listings mention 1,218 females, including both adults and children. The document will be scrutinized in future studies, but it can now be stated that it has recorded over a hundred female names with their variants. Thus, we have a unique opportunity to get familiar with the official Christian female nomenclature of the Karelian population of Ladogan Karelia and northwestern Russia in general at the turn of the 17 th century. Cf.

Mariya: mentioned 127 times in the following variants - Mariya, Mariyka, Mariza, Maritsa, Marika, Mariko, Manchko, Man'ka, Mar'eka;

Praskov'ya: mentioned 23 times, variants - Paraskovia, Paraskoviya, Paraska, Porasko, Pasoka;

Fevron'ya: mentioned 28 times, variants - Khovridka, Khovronitsa, Khovroshka, Khovrol'ya, Khovrosiya, Fevrol'ya, Fevrolka, Fevronitsa, Fevroniya, Fevrosiya;

Fedos'ya: mentioned 44 times, variants - Fedoz'ya, Fedoziya, Fedos'ya, Fedosiya, Fedositsa, Fedoska, Fedoshka, Fedochka, Fedoseyko;

Kseniya: mentioned 25 times, variants - Aksin'ya, Aksoska, Aksyuska, Oksemia, Oksenia, Oskinitsa, Oksin'ya, Oksinka, Oksyuka, Oksyutka, Oksyunko, ? Soksyutko, ? Soksyunka, ? Osyutka, ? Sosyutko. 
V.A. Nikonov has estimated that out of the several hundred names in the church calendar, only 74 names were used among Russian peasant women in the 18 th century. This is certainly an incomplete estimate, given that the counts did not cover the entire territory of Russia at that time. On the other hand, the number of female names in each specific case of the territories covered by the study was even lower - only 44 to 50 names. Besides that, the top 10 most common ${ }^{2}$ names, as the author of the study remarked, sufficed in the second half of the 18th century for the multimillion lot of Russian peasant women. Nikonov also concluded that a feature of the naming situation at that time was that there were very few female names that occurred uniquely or only a handful of times. The reason for this was that the naming tradition in many areas excluded the possibility of giving a name that was not the name of anyone else in the village (Nikonov 1971: 125-126).

Although we now have an idea about the female nomenclature on the Ladogan Karelia in the first half of the 17th century, we still have very little information about the native forms of the names that were in use in the Karelianlanguage milieu. Only very rarely can we say that one or another variant of the name was used as it is among Karelians at the time. We gained some knowledge of the Karelian-language vernacular forms as late as in the last third of the 19th - early 2oth centuries, when Finnish researchers of folklore started recording the names of folk poetry performers, cf. Bogdanoff Moarie (<Maria), Hermanoff Kat't'i i (< Yekaterina), Homon'e Vetora (< Fedora) (Niemi 1921: 1082, $1084,1089)$, etc. Somewhat more extensive is our knowledge of the situation in Finnish Karelia, since local forms of female names were recorded in some 18th century censuses, but their number is not very high either. Swedish sources on the territory of the former Karelian district (Karel'skij Uyezd) also contain some variants of female names from the 17th century. Compared to the total number of names and their variants recorded, inter alia, in the 1650/51 listing, known Karelian-language forms are very few.

At the same time, familiarity with the female nomenclature of the $17^{\text {th }}$ century Karelian population of Ladogan Karelia and the modern vernacular variants used in various Karelian-speaking territories (present-day Republic of Karelia, Tver Region, Leningrad Region and borderland Finnish Karelia) enables the identification of the earliest forms of female Christian names through comparisons. The assumption here is that the records of identical variants in the above-mentioned areas are the oldest forms that had been used in Ladogan Karelia prior to the major migration of Karelians to their current areas of residence in the first half of the 17th century. 
One can also suppose that variations of the same name indicate that we are dealing with a name with a longer history of usage among the Karelian population as compared to names with fewer variants.

\section{Examples of presumably early forms of the names Agaf'ya and Ol'ga:}

Agaf'ya: Ol'ga:

Ogo(i) Ol'o (southern dialects of Karelian Proper)

Okoi Ol'o (northern dialects of Karelian Proper)

Ogo Ol'o (southern dialects of Karelian Proper, Leningrad Region)

Ogo Ol'o (southern dialects of Karelian Proper, Tver Region)

Ogoi Ol'o(i) (Karelian sub-dialects in Finland)

Ogoi Ol'oi (Livvi Karelian)

Ogoi Ol'oi (Ludic Karelian)

The first documentary evidence of the Christianization of Karelians is dated to 1227, when Prince Yaroslav Vsevolodovich passed the respective order. It is since then that we can speak of a gradual arrival and advancement of the new religion in medieval Karelia. Over the course of the nearly 800 years since, Karelians have assimilated quite a number of Christian names, which have developed into multiple vernacular variants generated according to the phonetic and morphological norms of the Karelian language. The table below, for example, relays the vernacular forms of the name Maria in the Karelian language:

\begin{tabular}{|c|c|c|c|c|c|}
\hline Maču & Maija & Maikki & Maka & Maki & Man'a \\
\hline Man'ka & Man'ke & Manni & Man'oi & Man'u & Man'ukka \\
\hline Man'ukki & Manu & Mar’a & Mar'aša & Maraša & Mar'o \\
\hline Mar'u & Mari & Maria & Marija & Marie & Marikka \\
\hline Marikko & Marina & Mariška & Marja & Marju & Marjuška \\
\hline Maru & Masa & Maša & Mašoi & Massa & Mašši \\
\hline Mašukki & Miarjuška ${ }^{3}$ & Muarjuška & Maarie & Mååria ${ }^{4}$ & Muari \\
\hline Muarie & Muarii & Muarja & Muarjo & Muarjoi & Muarju \\
\hline Muard'a & Muaša & Muaški & Marja & $?{ }^{\star}$ Mairi & ? ${ }^{*}$ Mas'a $^{5}$ \\
\hline
\end{tabular}

Table 1: The vernacular forms of the name Maria in the Karelian language 


\section{Pre-Christian Karelian female names}

It took several centuries for the new system of Christian names to become established in Karelia. Before that, the medieval Karelian population had had its own pre-Christian system of personal names. According to the earliest documentary sources from the 16th century, however, a majority of the male population of Karelian territories had, at least officially, Christian names. On the other hand, in the first half of the 17 th century ${ }^{6}$ we still find documents with pre-Christian male names, both native and Old Russian, cf. a 1618 record from Suojärvi Pogost, Čiipakonniemi Village Liberå $\left({ }^{*}\right.$ Libero) ${ }^{7}$ and Kaucho ( ${ }^{*}$ Kauko) Muliakof (IK 1987: 363), a 1629 record from Tiurala Pogost, Petkola Village Michitta Häränpoika (lit. son of the Bull), and from Lauroila Village Timoska Migriläinen and his grandson Pervo (Russ. ${ }^{*}$ Первой 'first') (IK 1993: 356, 364); a 1637 record from Madiala Village of Sortavala Pogost - Achti Ivanof (IK 1991: 375) and from Illiala Village Pälkijärvi Pogost - Martyn Nyrick Kurkojev (IK 1991: 305, 676); in Taipale in Liperi Pogost - Malafej Ihalempiof Kerkkänen (1657) (Saloheimo 2010: 200).

As mentioned above, names of Karelian women in 16th-17th century written sources occur only sporadically, and all of these are already of a Christian nature. However, there is one exception: in the village of Savioja in the Kurkijoki Pogost mentions Maima Ulasies Änckia (i.e. Vlas's widow Maima) (1637) (IK 1991: 86), whose name is likely to be of prehistoric origin (cf. Kar. maima 'small fish; young fish' $\rightarrow$ *'small; short-statured' ${ }^{*}$. A similar situation was observed in the neighboring Russian-speaking territories. One may remark, however, that 17th century written sources for other regions of Russia still contain some, albeit scarce, pre-Christian female names: viz. widows Goluba Ignat(')iva (Голуба Игнат(ь)ива), Neupokoy's wife Lyubavka (Неупокоевская жена Любавка), Kunavka Ivanova (Kyнавка Иванова) (DK 1623: 46 ob, 49-49 ob); Pavel Potrekeyev with his wife Dosada (Досада 'displeasure') and the prayer name - Matrena Pavel's daughter (1637), maiden Dashka daughter of Yakov, but nicknamed Soroka (Сорока 'magpie') and the prayer name Pigas'ya (1637) (DG 1637: 2-3). Stepanova (2006) observed that the total number of Old Slavic female names recorded in dictionaries by N.M. Tupikov, S.B. Veselovskiy and M. Moroshkin was not more than ${ }^{10}$ sixty units. On the other hand, the $1650 / 51$ list of Karelian migrants points to quite a few more pre-Christian names of Russian origin in use at that time, at least among the Karelian population 
of the Ladoga region, viz. Durka, Goriska, Kozyutka, Maresyanka, Nasonilka, Onositsa, Salanko, Solvenko, Iyelgiya (Saloheimo 1992). It cannot, of course, be ruled out that some of these are actually variants of some Christian names whose corresponding original forms have not yet been identified.

Compared to native pre-Christian male names, traces of which can be found not only in documents but also in modern surnames of Karelians and Finns, female non-calendar names are completely unknown among the local Finnic population, at least at the documentary level, even in Russified form. Currently, the main source of the pre-Christian onomasticon of Finnic peoples is oral folk poetry. Examples of female names found in this material are Lokka, Piltikkä, Rauni, Pal'l'oi, Pal'l'oni, Ainikki, Mimerkki, Mielikki, Tuulikki, Tuuvikki, Tyynikki, Tyytikki, Vuohikki, Slavnikki, Loviatar, Kuutar, Melutar, Päivätär (SKVR ${ }^{11)}$ ), etc. In addition to folklore texts, there is another important source from which information about the pre-Christian onomasticon of medieval Karelians can be derived. This source is pet and livestock names, especially cow names with the suffix $-k k i^{12}$. The examples above show that this suffix is quite often present in female names in oral folk poetry.

The study of Karelian-language names given to cattle has demonstrated that the same anthroponymic bases can be found behind them as in oral folk poetry. Modern cow names are often based on female Christian names. In Finland, for instance, such cow names were recorded already in the 18th century (Ojansuu 1912: 34). We believe this situation can also be projected back to an earlier period, when profound changes associated with the increasing introduction and utilization of the new Christian naming system were taking place in the female onomasticon of Finnic peoples late in the medieval period. The old non-calendar system of female names has not, however, vanished without a trace, but has persisted through transfer to another linguistic level, i.e. to the practices of naming pets and livestock, in particular cattle. In other words, quite a few Karelian-language cow names in use today have medieval female names behind them. Even more of such names can be found among cow names in the Finnish language. The influence of the Russian language and culture has for a long time been exerted on all levels of the Karelian language, especially in the southern parts of Karelia and in the Tver Region. This can be seen also in the naming of livestock. To put it another way, Livvi and Ludic Karelian, as well as the Karelian Proper dialects of the Tver and Leningrad Regions, now 
have very few native names for livestock, since these have been supplanted by borrowings from Russian: cf. Belka, Bel'ka, Pel'a 'white', Rižuha 'red', Pestruha 'variegated', Buura, Buuroi, Buurikki 'brown', Krasotka 'pretty', Zor'ka 'born at dawn', Nočka 'born at night', Marta 'born in March', Dun'a, Daška, Lukoi, Lukerju, Sil'va, Maška (female names), etc.

It can be stated that the bulk of the traditional cow onomasticon in the Karelian language has been lost irretrievably, since it has never been collected specifically, and hundreds of pre-Christian Karelian female names have "sunk into oblivion" by proxy. Cattle names in the Karelian language, however, partially coincide with the cow onomasticon in Finland and Estonia. This fact suggests that the cow names used by Karelians, Finns and Estonians may have common Finnic pre-Christian names behind them. Below are some examples of anthroponymic bases common to folk poetry and Karelian-language names of cows, cf. in folklore: Ainikki, Ainikki ${ }^{13}$ Turuzenpoiga, Aino - cows: Kar. Ainikki, Ainikko, Aino, Finn. Ainikki, Ainike; Kyllikki - Kar., Finn. Kylli, Kyllikki; Mielikki - Kar., Finn. Mielikki; Suovakko - ? Kar. Suobikki, Suopo(i), ? Finn. Aikasuopa, Suovi; Lemmingöine - Kar., Finn. Lemmikki; Tähetär - Kar. Tähikki, Tiähti, Finn. Tähikki, Tähdikki.

The following cow names have the same bases as attested e.g. in the pre-Christian male onomasticon of Finnic peoples: male name JoutsiKar. Joučikki, Joučči, Finn. Jouhtikki; male name Kyllätty - Kar., Finn. Kyllikki; male name Lemmitty - Kar., Finn. Lemmikki, Lempi; village Mairi/la (1618, Korel'skij Uyezd) - Kar., Finn. Mairikki; male name Mielitty - Kar., Finn. Mielikki; male name Merikirja - Finn. Merikki, Finn. Kirjakka, Kar. Kirjo; male name Päiviö, Päiväkkä - Kar., Finn. Päivikki; male name Toija, village Toija/la - Kar. Toijo; male name Toivottu, Toivo - Kar., Finn. Toivikki, Toivoi, male name Valittu - Kar. Valikki.

There is evidence from folklore texts that the female onomasticon contained i.a. generic animal names, viz. Lokka 'gull', Kajavainen 'gull', Vuohikkit from vuohi 'goat', etc. In the Karelian onomasticon, names of animals are mainly represented among non-calendar male names, e.g. in 1629 in Petkola Michitta Häränpoika ${ }^{15}$ (lit. Nikita son of the Bull) (IK 1993: 356), in 1618 in Hyrsylä Jaakko Repånpoika Putto (lit. Yakov son of the Fox), and in Suojärvi Kondrato Kokonpoicha (lit. Kondrat son of the Eagle) (IK 1987: 360-361), etc. The Russian population had such pre-Christian female names as, for example, Korova 'cow', Shchuka 'pike', Kuritsa 'hen', etc. (Stepanova 2006). It is thus possible that Karelian-language cow 
names such as Lokka 'gull', Hanhikki from hanhi 'goose', Joučikki, Joučikoi and D'oučuoi from joučen 'swan', Piäsköi 'swallow', Peipo 'chaffinch' and Lindoi 'bird', as well as the sheep name Tikki from tikka 'woodpecker', are based on non-calendar female names. In Finland, the following faunal names have been given to cows: Alli 'long-tailed duck', Ahma 'wolverine', Tiira 'tern', Joukahainen from joukahainen 'swan', Sotka 'pochard', Orava 'squirrel'. while the name Peippo 'chaffinch' has been given to she-goats (NA). One of the names given to cows by the Veps is Hahkoi 'gray', cf. Kar. huahka 'mew gull; gray (referring to hair)'. The Russian population has also given their cows names associated with generic names of birds and animals, viz. ? Belka 'squirrel', Vorona 'crow', Galka 'jackdaw', ? Goluba 'dove', Lastochka 'swallow', Lebyodka 'swan', Lisa 'fox', Perepyolka 'quail', Soroka 'magpie'. Observe that the same names have been recorded among Russian pre-Christian female names.

Karelians have lived side by side with Russians for centuries. The female onomasticon of the latter has included pre-Christian female names such as Chernava, Belyana and Malyuta (associated, respectively, with the Russian words for black, white and small). The same names have been used as cow names in the Russian language. One can thus assume that Finnic peoples also once had female names such as Pienikki from pieni 'small', Mussikki, Mustikki, Muššukki or Muštikoi from musta ${ }^{16}$ 'black' and the sheep name Mučukki from mučči 'black', which are now used as livestock names. Finns have also named cows Valkonen, Valk $(k) o$ and Valkuna from valkoinen 'white', and Karelians have used the same base for the names of horses (Valko) and reindeer (Valkie).

In addition to the motifs mentioned above, the pre-Christian male onomasticon contains names pointing to the sequence and time of birth of boys in the family, e.g. Pervoi 'first', Vtoroi 'second', Trety'yak 'third', Chetvertak 'fourth', Pyatoi 'fifth' and Subbotka $a^{17}$ 'born on Saturday'. Similar bor rowed names have been recorded from among the Karelian population, cf. Pervo (< Первой), Piättö, Piätöi (< Пятой) > homestead name Piättöilä (White Sea Karelia), name Zubottu $(<$ Subbot $(k) a)>$ village Zubottalu (Olonets Karelia). Looking at the system of naming cows in Karelia, one can see that some of the names indicate the days of the cows' birth, e.g. Enčikki, Enčoi ${ }^{18}$, Endžikki, Endžoi, Ensikki' ${ }^{19}$, Ensoi 'born on Monday' (< 'first'); Toičikki, Toinikki ${ }^{20}$ 'born on Tuesday' (< 'second'); Kolm(u)oi $i^{21}$ 'born on Wednesday' (<'third'); Piäštikki, Piätkö 'born on Friday' (<'fifth'). Could it be so that the background of these names are the pre-Christian 
names, but in this case those of women, that could indicate either the day on which a child was born or the sequence of their birth in the family? Remarkably, such names based on days of the week were given in the Karelian milieu to cows but not to bulls.

The examples below are Russian pre-Christian names and Karelian-language cow names, presumably based on former female names, in which the same semantics can be discerned. Thus, they demonstrate some universalia in the naming of girls in Finnic languages and among the Russian population, cf. Russ. Goluba - Kar. Heluna, Russ. Gostena - Kar. Gostikki, Kostikki, Russ. Zhdana - Kar. Toivikki, Russ. Malyuta - Kar. Pienikki, Russ. Zabava Kar. Lysti(kki), Russ. Chernav(k)a - Kar. Mussikki, Muštikoi, Russ. Lyuba(va) - Kar. Lemmikki, Russ. Khotena - Kar. Haluna, etc.

One final remark that should be made here is that the dictionary by N. Tupikov (2005) includes around six thousand Russian pre-Christian names. This fact may suggest that the number of non-calendar names among Finnic peoples, namely Karelians, was probably also quite substantial. The materials above prove that modern cow names have preserved traces of at least some native female names used in the Middle Ages. Thus, further collection and study of Finnic names of pets and livestock can help to reveal new, previously unknown non-calendar names. It can be noted that in addition to the ones already identified, the Karelian language has quite a number of other cow names, including those with the suffix $-k k i$, which may possibly reveal other pre-Christian female names ${ }^{22}$, e.g. Kar. Halikki, Helmi(kki), Hermikki, Herukki, Hiilikki, Kauni(kki), Kortikki, Liipakko, Lysti(kki), Komi, Onnikki, Orvikki, Orvokki, Piirikki, Sorokki and Toirikki, as well as the sheep name Hamukki.

\section{Karelian Christian female names and their variants}

Let us recall here that according to the Laurentian copy of the Chronicle of Novgorod, the first Karelians were baptized in 1227, when Prince Yaroslav Vsevolodovich ordered the Christianization of Korela. Over the nearly 8oo-year-long history of Karelian Christianity, the Russian church onomasticon has gained a plethora of vernacular variants while being assimilated into the Karelian community. It should be remarked that up until the mid-2oth century, the Russian population used significantly fewer female names than male names. Thus, prior to the Mongol Invasion in the 1250s, Russian Orthodox liturgical texts and menologies contained 445 
male names and 72 female names. Apart from these, there were also some Greek names ( 92 male and 33 female) in use, which are not included in the church calendars and menologies. Thus, in the first tertial of the second millennium, there were 537 recorded male and 105 female names. Some of the names gradually fell out of use and were replaced by others. Eventually, by 1960 , the calendar contained 874 male and 228 female names (Superanskaya 1998: 29-30, 36).

It was after the event of official baptizing that the step-by-step accession of the new Christian names into the Karelian milieu began. Understandably, this was a long process, and it took until the 16th century for the "new" system of Christian names to be more or less internalized in a majority of Karelian-speaking territories, at least at the official level.

The female Christian onomasticon was made up of full-form canonical names such as Anastasiya, Luker'ya, Matrena (Matryona), Paraskeva, Setukhvina, Solomonida and Stepanida, to name a few. Many of these, however, were not used even by the Russian-speaking population of Karelia and the adjacent regions, and it was even rarer for such names to be taken directly into Karelian usage. Full baptismal names were already transformed into numerous vernacular forms in Russian territories. Their sound was therefore shaped by the phonetic and morphological rules of the Russian language at different historical periods, and they were often borrowed into the Karelian language in this pre-modified form.

As a rule, early Karelian vernacular forms of names comprise two syllables and differ from the original canonical variants in that they lack certain sounds, cf. e.g. Kar. As'o, Hodo, Lukki, Oni, Vemi - Russ. Anastasiya, Fedos'ya, Luker'ya, Anis'ya, Yefimiya. The forms of canonical names in use among Karelians thus suggest that at the beginning there was a clear tendency towards abridging the named borrowed into the Karelian language to two syllables. On the other hand, the contemporary Karelian onomasticon has quite many trisyllabic forms of names, some of which may be relatively "old".

Karelians assimilated the Christian onomasticon indirectly, via the Northern Russian dialects, with their own phonetic norms and rules. Some of these can still be seen in the Karelian-language anthroponymy, in both vocalism and consonantism.

One such phenomenon is the so-called okanye ${ }^{23}$, i.e. the differentiation between the vowels $o$ and $a$ in unstressed syllables. This trait appears at the very beginning of quite a number of names, where the initial $a$ in Russian 
full-form calendar names and their vernacular forms was changed to $o$, and the names or their forms were then borrowed into the Karelian language: cf. Kar. Okki, Okku < North Russ. Okulina < Ch. Akulina; Oka, Ogoššu < Ogaf'ya < Agaf'ya; Ol'o(i), Ol'ona < Olyona < Alyona. This phonetic feature of Northern Russian dialects is also visible in the anthroponymic material from cognate Finnic nations, as well as among the Saami population of the Kola Peninsula: cf. Veps. Okšu < Akulina, Ogroi < Agrafena, Onoi < Anis'ya; Seto (Estonia) Ouda < Avdot'ya, Oka < Agaf'ya; Saami Oggišk < Agaf'ya.

Another phonetic trait of Northern Russian dialects discernible in the Karelian anthroponymicon is the transition of the vowel $e$ to $o$ both initially and inside the word: cf. D'ougoi, Jouki - Yevgenia, Ol'o(i), Ol'ona - Yelena, Outi - Yevdokiya, Opičča, Ohkimie - Ye(v)fimiya, Opri, Oppo Yefrosin'ya, Hopo, Houri - Fevroniya.

Female names in the Russian language end in a vowel. Names ending in a vowel, usually an $-a$, are also common in Karelian-language forms. Name variants ending like this are primarily typical of Karelian Proper. In Livvi Karelian, the Karelian-Proper final vowel $a / a ̈$ in bisyllabic names is changed to $u / y$ when the first syllable is closed or when the word begins with a diphthong or a long vowel. The same applies to vowels in the last syllables of polysyllabic names, cf. among Livvi Karelians: Liizu - Yelizaveta, Muarju - Maria, Nikku - Nina, Teppu - Stepanida, Sofju - Sofiya, Vekku Vera, Nadinu - Nadezhda, Palagu - Pelageya, Parasken'n'u - Paraskov'ya, Tat't'anu - Tat'yana, etc. At present, however, owing to the assimilation processes and the ever wider use of traditional vernacular Russian forms ending in $-a /-y a(« \mathrm{a}, я »)$, this trait among Livvi Karelians occurs mainly in the language spoken by the older generation, and is becoming rarer even among them. Note also that in the Livvi and Ludic dialects, the final vowel in polysyllabic names in the nominative case can sometimes be dropped, cf. Jelen - Yelena, Nadin - Nadezhda, Okul'in - Akulina, Poluag - Pelageya, Tat't'an - Tat'yana, etc.

Karelian-language female names with the final vowel $-u$ are also present in the Karelian Proper dialect. It appears that at least some of these are diminutive forms of full personal names that must have been used when naming children at birth. Similar forms have also been recorded as variants of names in which the vowel $-u$ - is found in the original Russianlanguage canonical names, wherefore, on quite many occasions, the emergence of such vernacular forms with the final $-u$ in the Karelian language has nothing to do with diminutiveness. Cf. Kar.-Pr.: Akku, Okku - Russ. 
Akulina; An'u - Anna; Dar'u, Das'u - Dar'ya; Gan'u - Agaf'ya; In'u, Iru - Irina; Jelu, Jel'u - Yelena; Kat't'u - Yekaterina; Kretu - Kristina; Likku - Yelizaveta; Malu - Melan'ya; Man'u, Mar’u, Mašu - Maria; Muappu Marfa; Nattu, Nat'u - Anastasiya; Nat'u - Nadezhda; Od'u - Yevdokiya; Ogru - Agrafena, Agrippina; On’u - Alyona; Onu - Anis'ya; San'u - Aleksandra; St'epu - Stepanida, etc.

\section{Diphthongization and elongation of vowels}

One of the phonetic traits of the Karelian onomasticon is the elongation and diphthongization of the original stressed vowels in names. This process occurs because stressed vowels in the Russian language are pronounced slightly longer than unstressed ones, wherefore Karelians perceive them in Russian names as long or, at least, semi-long. Hence, the stressed vowel in the first open syllable is rendered by a long phoneme, and in some cases monophthongs are diphthongized. When the first syllable is closed, the vowel is usually not elongated, possibly owing partly to consonant gemination, cf. Kar. - Russ. Akuliina - Akulina; Alfiza - Anfisa; An'uusa - Anyusa (Anis'ya); Auvuusa - Avgusta; Daarju - Dar'ya; Hiekla - Fyokla; Iiro - Ira (Irina); Jeeva - Yeva; Juulia - Yuliya; Leena - Lena (Yelena); Liiska, Liiza-Liza (Yelizaveta); Lyyti, Lyyči - Lyuda (Lyudmila); Liidä-Lida (Lidiya); Miila - Mila (Lyudmila); Maarie, Muarjo(i) - Mar'ya (Mariya); Niija - Agniya; Poluaga - Palaga (Pelageya); Riitta - Rita (Margarita); Sarafina, Siima - Sima, Serafima; Sveet(t)a - Sveta (Svetlana); Sooja, Zooja - Zoya; Souhja, Šouhja - Sof'ya (Sofiya); Šuura - Shura (Aleksandra); Toon'a - Tonya (Antonina); Tyyne - Dunya (Yevdokiya); Veera, Vieruška - Verushka (Vera); Viija, Fiijo - Sofiya; Vuassa, Vuašši - Vassa, etc.

Rendering of the Russian final -еуa (-ея), -іуа (-ия), -'уa (-ья)

The Russian word-ending combinations -eya / -iya /-'ya in female names can be rendered in the forms borrowed by Karelians in different ways. As demonstrated by the examples below, the exact ending of the original Russian name was reflected in the rendering of the names; $\mathrm{cf}$.

-еуa as -еi: Joutokei - Евдокея; Klaudei - Клавдея; Lukerei - Лукерея; Oksei ( ${ }^{\star}$ Oksenei) - ${ }^{*}$ Аксенея; Parasei - ${ }^{*}$ Парасея (Парасковья); Taisei Таисея; Тиаге - ? ${ }^{\star}$ Дарея; 
-iya as -ia, -ie: An'usie - Анисия; Jeиdokia - Евдокия; Hodenia, Hetenie - Фетиния; Hourenia - Ховрония; Joukenia, Jougenie, Joukenie - Eвгения; Klaudia, Klaudie - Клавдия; Lukerie - Лукерия; Maаria, Muarie - Мария; Malania, Melania, Malanie - Малания; Nastasia, Nastas(s) ie - Анастасия; Ksеenia, Oksenie - Ксения, Оксения (Аксинья); Orefie - Aрефия; Natalia, Natalie - Наталия; Ohkemie, Ohkimie - Ефимия; Okahvia, Okahvie - Агафия; Omelie - Амелия; Parassie, Paraskie ${ }^{\star}$ Парасия, ${ }^{\star}$ Параския (Парасковья); Stерапіе, Террапіа - Степания; Ustenie - Устиния;

-iуa as -ija: Joudokija - Евдокия; Jougenija - Евгения; Niija - Агния; Iija, Viija, Vija - Сoøuя;

-iya as -i: Agahvi, Kaffi, Okahvi - Агафия; Fedos's'i - Федосия; Hedeni, Hерепі - Фетиния; Joukeni - Евгения; Klaudi - Клавдия; Lukeri Лукерия; Oidot't'i - Авдотия; Oksen'i - Аксения; Opros's'i - ? ^Апросия; Paras's' $i$ - ${ }^{\star}$ Парасия (Парасковья); Ust'ini - Устиния; Tuari - Дария;

-'ya as C'C’a (C’a) / C'C'u: Anis's'a, On'us's'a - Анисья; Fedos's'u, Vetos's'a - Федосья; Hоитоп'n'u - Ховронья; Irin'n'a, Irin'a, Irin'n'u - Иринья; Malan'n'a, Malan'n'u - Маланья; Nastas's'a, Nastas's'u - Анастасия; Natal'l'u - Наталья; Oksen'n'a, Oksen'n'u - Аксенья; Oprosen'n'a, Oprosen'a, Oprosen'n'u - Апросенья; Oudot't'a, Oudot't'u - Авдотья; Parasken'n'u - Параскенья (Парасковъя), Soloman'n'a - Соломанья; Tajis's'a, Tais'a - Таuсbя;

-'ya as -ja (in Liv. also -joi, -ju): Agafju, Ogafjoi, Ogafju - Агафбия; Anisja, Onisja - Анисья; Duarja - Дарья; Fedosja - Федосья; Havronja, Hourenja, Ноvrenjа - Ховронья; Irinja - Иринья; Lukerja - Лукерья; Marja, Muarja, Marju - Марья; Natalja - Наталья; Malanja - Маланья; Ofimja Ефимья; Oksenja, Oksenju, Senja - Аксенья; Oudotja, Oudotju - Авдотья; Sofja, Souhja - Софья; Solomanja - Соломанья;

other cases: An'uияа - ${ }^{\star}$ Анюса (Анисия ог Анисья); Darn'и - ${ }^{\star}$ Дарня (Дарья); Hedossa, Vietossa - ${ }^{\star}$ Федоса (Федосия or Федосья); Klaud'a Клавдия; Nastaššu - ${ }^{\star}$ Насташа (Анастасия or Анастасья); Ofimn'a -

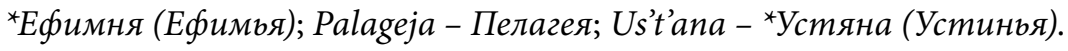


Changes can also be seen in the consonantism. To wit, the labial $f$ was for a long time missing from the Karelian language. A similar situation was observed in the Northern Russian dialects. As a result, the substitution of $f$ with $k h(« \mathrm{x} »)$ or $p$ in some names had already taken place in the Russian language, cf. e.g. Russ. dial. Okhim'ya (Охимья) - Yefim'ya, Khodora (Ходора) - Fedora, Oprosin'ya (Опросинья) - Ye(v)frosin'ya, etc. Thus, the original sound $f$ from the canonical names was rendered in the Karelian language by various consonants or a group of consonants, although in some cases the change was apparently mediated by the Russian dialectal forms of the names:

$\boldsymbol{f} \rightarrow \boldsymbol{h}(\boldsymbol{h}):$ Hegla, Helka, Hiekla - Фёкла; Hoto, Hedora - Федора; Hedossa, Hodo - Федосья; Hepeni, Hodenia - Фетинья; Serahhima - Серафима;

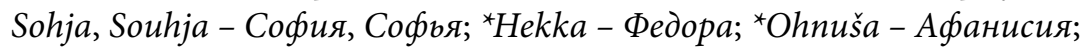

$\boldsymbol{f} \rightarrow \boldsymbol{h k}$ : Ohki, Ohkimie, Ohkemia - Aøuмья;

$\boldsymbol{f} \rightarrow \boldsymbol{h v}:$ Akahvi, Okahvi(e) - Агафья;

$f \rightarrow l$ (Ludic): ? Soloi - Coøuя;

$\boldsymbol{f} \rightarrow \boldsymbol{p}(\boldsymbol{p}) \rightarrow \boldsymbol{b}:$ Реbо - Федосья; Рети - Федосья; Агрріпа - Аграфена;

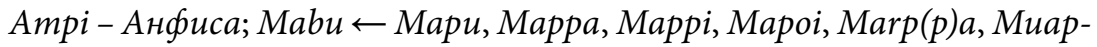
pa, Миарри - Russ. dial. Марna - Марфа; Opa, Opi, Oppi, Oppo, Opičča - Ефимия; Obri $\leftarrow$ Opri, Oprosen'n'u, Opros's'i, Opa, Oppi, Oppo, Ubri, Upri, Upro(i) - Опросинья - Е(в)фросинья; Pros'a - Russ. dial. Прося, Фрося - Ефросиния;

$\boldsymbol{f} \rightarrow \check{\boldsymbol{s}}(\check{\boldsymbol{s}}) / \boldsymbol{s}(\boldsymbol{s}) \rightarrow \check{\boldsymbol{c}}:$ Ogašši, Ogaššu, Ogašoi - Russ. dial. Ozama - Azaøbя; Marčči $\leftarrow$ Marssa Marš(š)a, Maršakka, Marši - Russ. dial. Mapua Mapфa; Glaša - Russ. dial. Глаша - Глафира; ? Ägräššie - ${ }^{*}$ Аррасия / ${ }^{*}$ Аграфия - Аграфена;

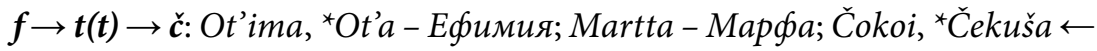
T'ekku, T'ekuša, T’oka, T'okki, T’okoi - Russ. dial. Текa - Фёкла; 
$\boldsymbol{f} \rightarrow \boldsymbol{v}:$ Vannukka - Афанасия; Vedora - Федора; Veki - Федосья; Sv'akla, Vekli - Фёкла; Vemi - Ефимия; Vija, Viija, Vio - Coфия; Vedossa, Vietos's'a - Федосья; Sv'akla - Фёкла;

The frequent matches for the Russian $g$ in Karelian anthroponymy are the consonants $h, k, v$. The $g-k$ transition most often takes places in the northern sub-dialects of Karelian Proper, which lack voiced consonants. Cf. ${ }^{\star}$ Kaffi, Oka, Okaša, Okku, Okahvie - Agaf'ya; Auvuusa - Avgusta; Jouki, Jeuhenie, ${ }^{\star} J e u h o-Y e v g e n i y a ;$ Palaka, Palakka, Palka, Pol'kka ( ${ }^{\star}$ Pol'akka) Pelageya; Ahri, Ahrippina, Arhippina, Krippa - Agrippina; Kal’u, Kalina - Galina; Oka, Okka, Ol'ka, Ol'ko, Ol'ha, Olkuoi - Ol'ga;

In borrowed names where $-v$ - occurs in front of another consonant, it is replaced by the vowel $-u-/-y$ - (sometimes $-i$-), which is paired with the vowel in front of it to form a diphthong: cf. Kar. - Russ. Auvuusa - Avgusta; Feuri, Houra, Houri, Houro, Hourenia - Khavron'ya; Jouk(k)i, Joutokei, Joude, Jeud'i, Jeygi, Oudi, Oudei, Oudoi, Oudotta, Audot'ja, Oudot'ju, Oute, Outi, Outti - Yevdokiya; Oiti, Oidot't'i - Yevdokiya; Klaudi(e), Klaud'a, Klaudei, Klaudii, Klaud'oi, Klauti, Klaut'a - Klavdiya; D'eugoi, Jeud'i, Jeygi, Jeuhenie, Jougi, Jouki, Jougenie, Joukeni(e), Jeuho - Yevgeniya; Maura, Mauro(i), Mauru - Mavra; Paula, Pauša, Paulina - Pavla, Pavlina. A transition of the diphthong ou into uo has also been recorded, cf. UotiЕвдокия (usually Outi).

Sometimes the Russian $v$ is replaced in Karelian regions by the consonant $b$ or $g$; cf. Barbara - Varvara; Magra, Magri - Mavra. In the first case, we are probably dealing with the influence of the Finnish language, since the name has been recorded from Karelians living in Finland, cf. Barbara - Barbara (Russ. Varvara). In the second case, one could suspect a mixing of the name variants Mavra and Makrida (cf. Kar. Makri - Russ. Makrida). This kind of transition, however, can also be seen in the appellative vocabulary, cf. Kar. mägrä, mäkrä, Finn. mäyrä 'badger'.

The consonant - $n$ - inside a name can be changed to - $m$-, cf. AmpiAnfisa. This transition conforms to the rule that the final consonant - $n$ - in the first of two adjacent words (e.g. denoting the genitive) is replaced in the colloquial language with - $m$ - if the next word begins with $-p-$. The consonant $-n$ - in front of $-m$ - in a consonant cluster will in some sub-dialects be assimilated, cf. Tomma, Tommo - Domna.

In contrast to male names, consonant blends at the beginning of female names are not very frequent. In fact, such word-initial combinations were 
for a long time atypical of the Karelian language as well as in Northern Russian dialects. Therefore, in such borrowings from the Russian language, one of two processes could occur: one of the consonants could be dropped from the combination or a vowel emerged between the consonants: cf. T'eppu, T'eppania - Stepanida; Sen'n'a - Kseniya; Parassa - Praskov'ya (cf. also Russ. Paraskeva); Kerttu - Krestina (Kristina).

Later on, Karelians adopted the use of two word-initial sequential consonants and the Karelian onomasticon thus acquired variants of the names with such combinations, e.g. Hrest' $i$, Hristoi, Kretu, Krestoi, Krestina - Krestina (Kristina); St'epu(kka), St’oša, Stepanie - Stepanida; Gluašši, Klakko, Klan'a, Klaudi - Klavdiya; Proša - Praskov'ya; Glaša - Glafira.

The reflex of the phoneme - $j$ - in some Karelian dialects is the palatal $d$ ' (or $t^{\prime}$ in anthroponymy), which can be found in quite a number of female names. This pattern occurs also inside the name: cf. D'eli - Yelizaveta; D'eli, D'el'u, D'elä, D’elkä - Yelena; D'eugoi - Yevgeniya; Aksen'd'a - Aksin'ya, Muard'a - Mar'ya ( $\leftarrow$ Maria); Šoft'a - Sof'ya, ? Lid'd'i - ${ }^{\star}$ Lid'ya - Lidiya; ? Tad'd'ana - Tat'yana.

The general pattern in the northern sub-dialects and some southern sub-dialects of Karelian Proper in borderland Finnish Karelia is that the names have unvoiced instead of voiced consonants $(d \rightarrow t ; g \rightarrow k ; b \rightarrow p)$ : Tomma - Domna; Tuarie - Dar'ya; Kalina, Kal'a.

Another distinctive feature of the vernacular female onomasticon is that there appeared the forms in which the usually strongly palatal consonant $d^{\prime}, t^{\prime}$ or $s^{\prime}$ was changed to the affricate ${ }^{24} \check{c}, d \check{z}$ (cf. Kuzmin 2016, 71-73):

$\boldsymbol{t}^{\prime}\left(\boldsymbol{t}^{\prime}\right) \boldsymbol{V}, \boldsymbol{d}^{\prime} \boldsymbol{V} \rightarrow \check{\boldsymbol{c}}(\check{c}) \boldsymbol{V}$ (name-internally): Ančoi, Ančuri - ${ }^{\star} A n^{\prime} t^{\prime} V-A n^{\prime} t y a$ $\leftarrow$ Anna; Klaučči - ${ }^{*}$ Klaut't'i - Klavdiya; Lyyči - Lyyt'i - Lidiya; Načči Nat't'i - Natal'ya; Nadžoi - Nad'oi - Nadezhda; Ouči - Out'i - Yevdokiya; Tačči - Tat't'i - Tat'yana; Maččuri - Matrena (Matyona);

$\boldsymbol{t}^{\prime} \rightarrow \check{\boldsymbol{c}}$ (name-initially): Čokoi, Čekuša - T’oka, T'ekuša - Teka $\leftarrow$ Fyokla;

$\boldsymbol{s}, \boldsymbol{s}^{\prime} \rightarrow \check{\boldsymbol{c}}$ (name-initially): Čikki - S'ikli - Sinkletikiya, Čolo - Solo - Solomanida;

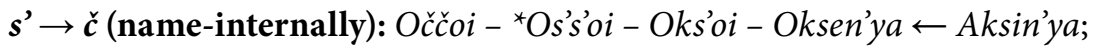
$\boldsymbol{s}^{\prime} \boldsymbol{t}^{\prime} \boldsymbol{V} \rightarrow \check{\boldsymbol{c}}(\check{\boldsymbol{c}}) \boldsymbol{V}$ (name-internally): Načči, Načču - Nas't'i - Anastasiya. 
In summary, it is safe to say that the modern names of Karelian women fit quite well into the general Karelian naming system, which emerged during the second millennium in close contact with the system of personal baptismal names of the Russian population. We believe that further study of the female onomasticon of the Karelian population, both pre-Christian and Christian, is a promising step on the way to a comprehensive description of the Karelian anthroponymic system. Furthermore, a systemic study of Karelian female names, as well as the naming systems of other nations, both cognate and unrelated, offers a unique opportunity to reconstruct the Russian forms of female names used in the Russian-speaking territories at least in the 16th century and probably even earlier.

\author{
Denis Kuzmin \\ Helsingin yliopisto \\ Suomalais-ugrilainen ja \\ pohjoismainen osasto \\ PL 24 \\ FI-ooo14 Helsingin yliopisto
}


From the Middle Ages to modern times: the Karelian female name system

\section{Notes}

1 University of Helsinki: "Personal name systems in Finnic and beyond: reconstructing the concepts of name giving in cultural layers of prehistory"; ILLH: tema AAAA-A18-118012490344-5 "Pribaltijsko-finskije jazyki Severo-Zapada Rossijskoj Federatsii: lingvisticheskije issledovanija v sotsiokul'turnom kontekste".

2 From more to less common: Yevdokiya (var. Avdot'ya), Anna, Praskov'ya, Matryona, Mariya, Marfa, Irina, Kseniya, Dar'ya, Yekaterina (Nikonov 1971: 138-139).

3 The Kondushi sub-dialect of Livvi Karelian in the Leningrad Region and the Vesjegonsk sub-dialect of Karelian Proper in the Tver Region have the back vowel $\underline{i}$ «ы» as the first component of the diphthong i $a\left({ }^{*} u a\right)$ : cf. mia $\left({ }^{*} m u a\right)$, litrie (part. ${ }^{*}$ litrua).

4 In the Padany sub-dialect of Karelian Proper, the diphthong oa has developed into a long $\bar{o}\left({ }^{\star} o a>o o\right)$, which we relay using the symbol åa. This rendition was suggested by the Finnish researcher Pertti Virtaranta and is based on the Swedish graphic system. In the Swedish language, this symbol represents a vowel with similar characteristics. At the same time, we see that historically this word had a long $\bar{a}$.

$5{ }^{*}$ An asterisk marks the names reconstructed relying on co-existent forms.

6 Cf. also Karelian traders in Port of Oulu in 1553: Ignatta Sixtuksenpoika, Nousia Riionpoika, Musta, Vaseli Ihanpoika (Nevalainen 2016: 15).

7 Cf. libero 'small fish', cf. also liberö 'adulatory person; unreliable person' (KKS).

8 Cf. in Kalevala: the spirit of the forest, the god of hunting Nyyrikki Tapionpoika; cf. also Dimitrejko Nyrakof (1637) (IK 1991: 300).

9 Cf. house name in Aunus Karelia: Maimankodi (family name - Maima, surname Mal'kov (Tekaččula, Tuuksi).

10 One can suppose, however, that the number of identified female names has somewhat increased since then.

11 SKVR, or Suomen Kansan Vanhat Runot 'the ancient poems of the Finnish people', is a 34-part work in which the majority of the original sources of Kalevala-type poetry are published.

12 See also Aspelin 1886: 3, Forsman 1891: 190-192.

13 Cf. Rus. pre-Christian male name Odinets (Одинеи, 'single': blacksmith Odinets Ivanov, 1568, fortress town of Korela) (IK 1987: 62), surname Odintsov (Čuppu, Martniemi).

14 Cf. the contemporary name given to cows by Livvi Karelians Kozočka ( ${ }^{\star}$ Vuohikki) (cf. Kar. vuohi 'she-goat').

15 In some cases, it also could be a nickname. The documents contain i.a. examples of names where the determinant - poika appears as a substitute for the name with a -nen suffix that has been mentioned in the connection with the same person. In this case it does not necessarily refer to a patronymic.

16 Cf. Karj. lamb name Musturi 'the name of a black lamb' as well as Ivanko Mikiforov Mustar (1563, Shunga pogost) (PKOP: 149), Sauka Mussarin = Savka Muzurin (IK 1991: 309, 678) $\rightarrow$ personal name ${ }^{\star}$ Musari, ${ }^{\star}$ Musuri, ${ }^{\star}$ Musturi.

17 Cf. Subotka Koreljanin (= Karelian) (1597, Puanajärvi pogost), Subotka Petrov (1597, Puanajärvi pogost) (IK 1987: 217).

18 Cf. Ivanko Enčojev $\leftarrow{ }^{\star} E n c ̌ o(i)(\mathrm{IK}$ 1991: 636). 
19 Cf. deserted space Änsikass Ödhe $\leftarrow{ }^{\star}$ Ensikkä (IK 1991: 430).

20 Cf. ? village Toinino Korbassa (1500, Korela province) $\leftarrow{ }^{\star}$ Toine (PKVP: 549 ).

21 Cf. Juško Dmitriyev syn Kolmoyev (1678, Roukkula, Repola pogost) $\leftarrow{ }^{\star}$ Kolmoi (PK 1678: 127).

22 Since the relationship between modern cow names and female names is a hypothesis, this should be proven as far as possible. It requires special research in which, among other things, it is necessary to highlight the content of the animal names and reflect on why such a name was given to a calf and whether the same name could in fact be given to a girl. It seems that not all known cow names were used as female names. Some of them emerged at different times and in different areas, according to the - $k k i$-model. On the other hand, a good example might be the cow name Karj.

23 Okanye is a phonetic feature intrinsic to a number of the East Slavic dialects. It exists to distinguish the vowel quality of an unstressed [o] and [a].

24 One can also mention here that the female onomasticon contains several trisyllabic names with affricates in the final syllable, which takes the form $\check{c} \check{c} V$. Such suffixal variants are likely to be the diminutive forms of Karelian-language Christian names, cf. Anničča - Anna, Heglačču - Fekla, Matričča - Matrena (Matryona), *Olličča Ol'ga, Opičča - Yefimiya. It is less probable, although possible, that such variants appeared under the influence of Russian-language forms such as Annitsa (Анница), Olitsa (Олица), etc.

\section{Abbreviations referring to languages and dialects}

Ch. Old Church Slavic language

Finn. $\quad$ Finnish language

Kar. Karelian language

Kar.-Pr. Karelian Proper

Liv. Kar. Livvi Karelian

North Russ. Northern dialects of the Russian language

Russ. Russian language

Saami Saami dialects of the Kola Peninsula

Veps. Vepsian language

\section{References}

Aspelin, Johannes Reinhold 1886: Nautaeläinten nimistö - Uusi Suometar. № 91. 3. $<$ https://digi.kansalliskirjasto.fi/sanomalehti/binding/26991?page=3> 9 October 2017

Снaikina 2006 = Чайкина Ю. И.: Именования женщин в новгородских берестяных грамотах XI-XIV вв. - Вопросы ономастики. № 3. 33-38.

DG 1637 = Духовная грамота 1637 года. Отдел рукописей Российской государственной библиотеки. Москва. Ф. 256. Кн. 47. Ед. 238. Л. $2,3$. 
DK 1623 = Дозорная книга 1623 года по городу Тобольску. РГАДА. Москва. Ф. 214. Кн. 1207.

Forsman, August Valdemar 1891: Tutkimuksia Suomen kansan persoonallisen nimistön alalta I. Pakanuuden aikainen nimistö. Yliopistollinen väitöskirja. Helsinki: Suomalaisen Kirjallisuuden Seuran kirjapaino.

Gromova 1979 = Громова А. П.: Антропонимия паданского говора карельского языка - Вопросы ономастики / отв. ред. А. К. Матвеев. Изд-во Урал. унта. № $13 \cdot 38-55$.

IK 1987 = История Карелии XVI-XVII вв. в документах. T. 1. Науч. ред. А. И. Копанев, А. Г. Маньков. Петрозаводск - Йоенсуу.

IK 1991 = История Карелии XVI-XVII вв. в документах. T. 2. Ред. И. А. Чернякова и др. КарНЦ РАН. Петрозаводск - Йоэнсуу.

IK 1993 = История Карелии XVI-XVII вв. в документах T. 3. Ред. И. А. Чернякова, К. Катаяла. КарНЦ РАН. Петрозаводск - Йоэнсуу.

KKS = Karjalan kielen sanakirja 1-6. Lexica Societatis Fenno-Ugricae XVI. Helsinki: Suomalais-Ugrilainen Seura.

КР 1678 = Книга переписная семи Лопских погостов Олонеикого уезда 1678 г. РГАДА. Москва. Ф. 1209. Оп. 1. Д. 8573.

Kuzmin 2016 = Кузьмин Д. В.: Христианские имена карелов - Bопросы ономастикu. Т. 13. № 2. 56-86.

KuZmin, Denis 2014: Vienan Karjalan asutushistoria nimistön valossa. PhD dissertation. Helsingin yliopisto.

NA $=$ Suomen nimiarkisto. Helsinki.

Nevalainen, Pekka 2016: Kulkukauppiaista kauppaneuvoksiin: itäkarjalaisten liiketoiminta Suomessa. Helsinki: Suomalaisen Kirjallisuuden Seura.

Niemi, Aukusti 1921: Vienan läänin runonlaulajat ja tietäjät. Helsinki: Suomalaisen Kirjallisuuden Seura.

Nikonov 1971 = Никонов В. А.: Женские имена в России XVIII века - Этнограбия имен. Отв. ред. В. А. Никонов. Наука. Москва. 120-141.

Nissılë, VILJO 1976: Suomen Karjalan ortodoksinen nimistö. Joensuu: Karjalaisen kulttuurin edistämissäätiö.

OjansuU, Heıkк 1912: Kotieläintemme suomenkielinen nimistö. Helsinki: Kirjapainoosakeyhtiö Sana.

Parfenova = Парфенова Н. Н.: Русские женские имена: историко-культурный аспекm. <http://www.rusnauka.com/4_SND_2015/Philologia/7_186477.doc.htm> 9 October 2017

Paulaharju, SAmuli 1924: Syntymä, lapsuus ja kuolema: Vienan Karjalan tapoja ja uskomuksia. Kalevalaseuran julkaisuja; 2. Porvoo: WSOY.

PetrovsкiY $2000=$ Петровский Н. А.: Словарь русских личных имен. Русские словари. Москва.

РК 1678 = Переписная книга Кольского уезда корельских Ребольских волостей стрелецкого головы Кольского острога Ивана Власова сына Стариова 1678 года. РГАДА. Москва. Ф. 1209. ОП. 1. Д. 15056. Л. 97-154 об.

PК 1707 = 707-го году. Книга переписная Алексея Федоровича Головина да Андрона Васильевича Апрелева за их руками. РГАДА, Москва. Ф. 1209, Оп. 1, Д. 8579.

PКОР = Писиовые книги Обонежской Пятины: 1496 и 1563 г2. / под общ. ред. М. Н. Покровского. Изд-во АН СССР. Ленинград. 1930. 


\section{Denis Kuzmin}

PKVP = Переписная окладная книга Водской пятины $70 о 8$ (150о) года. Часть 2. Временник Московского общества истории и древностей российских. Москва. 1851.

Saloheimo, Veijo 1992: Bezhetskin ylängön karjalaisluettelo vuosilta 1650-1651. Joensuun yliopisto: Karjalan tutkimuslaitoksen monisteita 5.

Saloheimo, Veijo 2010: Entisen esivallan alle uusille elosijoille. Ortodoksikarjalaisten ja inkeroisten poismuutto 1500- ja 1600-luvuilla. Joensuu: Pohjois-Karjalan historiallinen yhdistys.

SKVR = Suomen kansan vanhat runot. $<$ https://skvr.fi/> 9 October 2017

STEPANOVA 2006 = Степанова Ф. В.: Русский женский антропонимикон в культурно-генетическом аспекте. Дис. канд. филол. наук / Краснояр. гос. ун-т. Лесосибирск. <http://www.lib.ua-ru.net/diss/cont/180473.html> 9 October 2017

SuperanskaYA 1998 = Суперанская А. В.: Словарь русских личных имен. АСТ. Москва. Tupiкоv 2005 = Тупиков Н. М.: Словарь древнерусских личных собственных имен.

Подгот. изд. и предисл. Ф. Б. Успенского. Языки славянских культур Москва.

USPENSKIY 1969 = Успенский Б. А.: Из истории русских канонических имен. Изд-во Моск. ун-та. Москва.

VeselovskiY 1974 = Веселовский С. Б.: Ономастикон. Москва: Наука.

Virtaranta, Pertti 1972: Polku sammui. Helsinki: Kirjayhtymä.

Virtaranta, Pertti 1992: Tverinkarjalaisista nimistä. Suomalais-Ugrilaisen Seuran Toimituksia 209. Helsinki: Suomalais-Ugrilainen Seura.

ZININ 1972 = Зинин С. И.: Введение в русскую антропонимику. Ташк. гос. ун-т. Ташкент.

\section{Anthroponymic material}

\begin{tabular}{|l|l|l|l|l|}
\hline Ainikki & Ainikko & Aino & Enčikki & Enčoi \\
\hline Endžikki & Endžoi & Ensikki & Ensoi & Gostikki \\
\hline Halikki & Haluna & Hamukki & Hanhikki & Helmi(kki) \\
\hline Heluna & Hermikki & Herukki & Hiilikki & Joučikki \\
\hline Joučči & Joučikoi & Joučuoi & Kauni(kki) & Kirjo \\
\hline Komi & Kortikki & Kostikki & Kylli(kki) & Lemmikki \\
\hline Liipakko & Lindoi & Lokka & Lysti(kki) & Mairikki \\
\hline Mielikki & Mučukki & Mussikki & Mustikki & Muštikoi \\
\hline Onnikki & Orvikki & Orvokki & Peipo & Pienikki \\
\hline Piirikki & Piäsköi & Piäštikki & Piätkö(i) & Päivikki \\
\hline Sorokki & Suobikki & Suopo(i) & Tikki & Toičikki \\
\hline Toinikki & Toijo & Toirikki & Toivikki & Toivoi \\
\hline Tiähti & Tähikki & Valikki & Valk(k)o & Vuohikki \\
\hline
\end{tabular}

Table 2: Livestock names $\rightarrow{ }^{\star}$ pre-Christian female names 
From the Middle Ages to modern times: the Karelian female name system

\begin{tabular}{|c|c|}
\hline Russian Christian names & Karelian-language forms of Christian female names \\
\hline Августа & Auvuusa \\
\hline Агафья & $\begin{array}{l}\text { Agafju, Agahvi, Gan’u, Kaffi, Okahvi, Ogafjoi, Ogafju, } \\
\text { Ogašši, Ogaššu, Ogašoi, Ogo, Ogoi, Ogoššu, Okahvia, } \\
\text { Okahvie, Oka, Okaša, Okoi, Okku }\end{array}$ \\
\hline Агния & Niija \\
\hline Аграфена & Arppina, Ogru, Ägräššie \\
\hline Агриппина & Ahri, Ahrippina, Arhippina, Arppina, Krippa, Ogru \\
\hline Аксинья & $\begin{array}{l}\text { Aksen'd'a, Kseenia, Oččoi, Oks'oi, Oksei, Oksen'i, Ok- } \\
\text { senie, Oksen'n'a, Oksen'n'u, Oksenja, Oksenju, Senja }\end{array}$ \\
\hline Акулина & Akku, Akuliina, Okki, Okku, Okul'in \\
\hline Александра & San'u, Šuura \\
\hline Алёна & Ol’o(i), Ol’ona, On'u \\
\hline Амелия & Omelie \\
\hline Анастасия & $\begin{array}{l}\text { As'o, Načči, Načču Nas't'i, Nastas's'a, Nastas's'u, } \\
\text { Nastaššu, Nastasia, Nastas(s)ie, Nattu, Nat'u }\end{array}$ \\
\hline Анисья & $\begin{array}{l}\text { Anisja, Anis's'a, An'uusa, An'usie, On'us's'a, Onisja, } \\
\text { Oni, Onu }\end{array}$ \\
\hline Анна & An’u, Ančoi, Ančuri \\
\hline Антонина & Toon’a \\
\hline Анфиса & Alfiiza, Ampi \\
\hline Арефия & Orefie \\
\hline Афанасия & ${ }^{*}$ Ohnuša, Vannukka \\
\hline Варвара (Барбара) & Barbara \\
\hline Василиса & Vuašši \\
\hline Bacca & Vuassa \\
\hline Bepa & Veera, Vieruška, Vekku \\
\hline Галина & Kalina, Kal'a, Kal'u \\
\hline Глафира & Glaša \\
\hline Дарья & $\begin{array}{l}\text { Darn'u, Dar'u, Das'u, Daarju, Duarja, Tuarei, Tuari, } \\
\text { Tuarie }\end{array}$ \\
\hline Домна & Tomma, Tommo \\
\hline $\begin{array}{l}\text { Е(в)фросинья } \\
\text { (Опросинья) }\end{array}$ & $\begin{array}{l}\text { Obri, Opri, Oprosen'n'a, Oprosen'a, Oprosen'n'u, } \\
\text { Opros's'i, Opa, Oppi, Oppo, Opri, Pros'a, Ubri, Upri, } \\
\text { Upro(i) }\end{array}$ \\
\hline
\end{tabular}




\begin{tabular}{|c|c|}
\hline Russian Christian names & Karelian-language forms of Christian female names \\
\hline Ева & Jeeva \\
\hline Евгения & $\begin{array}{l}\text { D’eugoi, D’ougoi, Jeud'i, Jeygi, Jeuhenie, }{ }^{\star} J e u h o, \text { Jougi, } \\
\text { Jouki, Jougenie, Jougenija, Joukeni, Joukenia, Joukenie }\end{array}$ \\
\hline Евдокия (Авдотья) & $\begin{array}{l}\text { Audot'ja, Jeudokia, Jeud'i, Jouk(k)i, Joutokei, Joude, } \\
\text { Joudokija, Od'u, Oidot't'i, Oiti, Ouči, Oudi, Oudei, } \\
\text { Oudoi, Oudotta, Oudot't'a, Oudot't'u, Oudotja, } \\
\text { Oudot'ju, Oute, Outi, Outti, Tyyne, Uoti }\end{array}$ \\
\hline Екатерина & Kat't'i, Kat't'u \\
\hline Елена & $\begin{array}{l}\text { D’eli, D’el'u, D’elä, D’elkä. Jelen, Jelu, Jel'u, Leena, } \\
\text { Ol’o(i), Ol'ona }\end{array}$ \\
\hline Елизавета & D’eli, Liiska, Liiza, Liizu, Likku \\
\hline Е(в)фимия (Афимья) & $\begin{array}{l}\text { Ofimja, Ofimn’a, Ohki, Ohkimie, Ohkemia, Ohkemie, } \\
\text { Ohkimie, Opa, Opi, Oppi, Oppo, Opičča, Ot’ima, } \\
{ }^{*} \text { Ot’a, Vemi }\end{array}$ \\
\hline Зоя & Sooja, Zooja \\
\hline Иринья (Ирина) & In’u, Iiro, Iru, Irin'n’a, Irin'a, Irin'n'u, Irinja \\
\hline Клавдия & $\begin{array}{l}\text { Gluašši, Klakko, Klan’a, Klaučči, Klaud’a, Klaudei, Klau- } \\
\text { di, Klaudia, Klaudie, Klaudii, Klaud’oi, Klauti, Klaut'a }\end{array}$ \\
\hline Крестина (Кристина) & Hrest'i, Hristoi, Kerttu, Kretu, Krestoi, Krestina, Kretu \\
\hline Ксения & Sen'n'a \\
\hline Лидия & Liidä, Lid'd'i Lyyči, Lyyt'i \\
\hline Лукерея & Lukerei, Lukeri, Lukerie, Lukerja, Lukki \\
\hline Людмила & Miila \\
\hline Мавра & Magra, Magri, Maura, Mauro, Mauroi, Mauru \\
\hline Макрида & Makri \\
\hline Маланья & $\begin{array}{l}\text { Melania, Malania, Malanie, Malanja, Malan'n'a, } \\
\text { Malan'n'u, Malu }\end{array}$ \\
\hline Маргарита & Riitta \\
\hline Мария & $\begin{array}{l}\text { Moarie, Maču, Maija, Maikki, ? }{ }^{\star} \text { Mairi, Maka, Maki, } \\
\text { Man'a, Man'ka, Man'ke, Manni, Man’i, Man'u, } \\
\text { Man'ukka, Man'ukki, Manu, Mar’, Mar'aša, Maraša, } \\
\text { Mar’o, Mar'u, Mari, Maria, Marija, Marie, Marikka, } \\
\text { Marikko, Marina, Mariška, Marja, Marju, Marjuška, } \\
\text { Maru, }{ }^{\star} \text { Mas'a, Masa, Maša, Mašoi, Massa, Mašši, } \\
\text { Mašukki, Miarjuška, Muarjuška, Maarie, Måaria, } \\
\text { Muari, Muarie, Muarii, Muarja, Muarjo, Muarjoi, } \\
\text { Muarju, Muard'a, Muaša, Muaški, Marja }\end{array}$ \\
\hline
\end{tabular}


From the Middle Ages to modern times: the Karelian female name system

\begin{tabular}{|c|c|}
\hline Russian Christian names & Karelian-language forms of Christian female names \\
\hline Марфа (Марша) & $\begin{array}{l}\text { Mabu, Mapu, Mappa, Mappi, Mapoi, Marpa, Marppa, } \\
\text { Marčči, Marssa, Marša, Maršša, Maršakka, Marši, } \\
\text { Martta, Muappa, Muappu }\end{array}$ \\
\hline Матрена & Maččuri \\
\hline Надежда & Nadžoi, Nad'oi, Nadin(u), Nat'u \\
\hline Наталия & Načči, Natalia, Natalie, Natalja, Natal'l'u, Nat't'i \\
\hline Нина & Nikku \\
\hline Ольга & Oka, Okka, Ol'ka, Ol'ko, Ol'ha, Olkuoi, Ol’o Ol’oi \\
\hline Павла (Павлина) & Paula, Pauša, Paulina \\
\hline Парасковья & $\begin{array}{l}\text { Paras's'i, Parassie, Paraskie, Parasei, Parasken'n'u, Pa- } \\
\text { rassa, Proša }\end{array}$ \\
\hline Пелагея & $\begin{array}{l}\text { Palageja, Palagu, Palaka, Palakka, Palka, Pol'kka, } \\
\text { Poluag(u), Poluaga }\end{array}$ \\
\hline Светлана & Sveeta, Sveetta \\
\hline Серафима & Sarafiina, Serahhima \\
\hline Синклетикия & Čikki, S’ikli \\
\hline Соломанида & Čolo, Solo, Solomanja, Soloman'n'a \\
\hline София & $\begin{array}{l}\text { Fiijo, Iija, Sofja, Sofju, Sohja, Soloi, Souhja, Šoft'a, } \\
\text { Šouhja Viija, Vija, Viija, Vio }\end{array}$ \\
\hline Степанида & St'epu, St'epukka, Stepanie, St’oša, T'eppu, T’eppania \\
\hline Таисья & Tais’a, Taisei, Tajis's’a \\
\hline Татьяна & Tačči, Tad'd'ana, Tat't’an, Tat't’anu, Tat't'i \\
\hline Устинья & Ustenie, Ust'ini, Us't'ana \\
\hline Федора & ${ }^{\star}$ Hekka, Hoto, Hedora \\
\hline Федора & Vedora, Vetora \\
\hline Федосья & $\begin{array}{l}\text { Fedosja, Fedos's'i, Fedos's'u, Hedossa, Hodo, Pebo, } \\
\text { Pemu, Vedossa, Vetos's'a, Vietos's'a, Vietossa, Veki }\end{array}$ \\
\hline Фёкла & $\begin{array}{l}\text { Čokoi, }{ }^{* C ̌ e k u s ̌ a, ~ H e g l a, ~ H e l k a, ~ H i e k l a, ~ S v ' a k l a, ~ T ’ e k k u, ~} \\
\text { T’ekuša, T’oka, T'okki, T'okoi, Vekli }\end{array}$ \\
\hline Фетиния & Hedeni, Hepeni, Hetenie, Hodenia, \\
\hline $\begin{array}{l}\text { Ховронья (Хавронья, } \\
\text { Феврония) }\end{array}$ & $\begin{array}{l}\text { Feuri, Hopo, Havronja, Hourenia, Hourenja, Hovren- } \\
\text { ja, Houron'n'u, Houra, Houri, Houro }\end{array}$ \\
\hline Юлия & Juulia \\
\hline
\end{tabular}

Table 3: Christian female names 